\title{
FAKTOR YANG DIDUGA MENJADI RESIKO PADA ANAK DENGAN RINITIS ALERGI DI RSU DR. CIPTO MANGUNKUSUMO JAKARTA
}

\section{SUSPECTED RISK FACTORS OF PEDIATRIC PATIENTS WITH ALLERGIC RHINITIS IN DR. CIPTO MANGUNKUSUMO HOSPITAL, JAKARTA}

\author{
Ganung Harsono, Zakiudin Munasir, Sjawitri P Siregar, HEM Dadi Suyoko, Mia Kumiati, Rita Evalina, Ratih D Palupi \\ Divisi Alergi-Imunologi, Departemen IImu Kesehatan Anak Fakultas Kedokteran Universitas Indonesia / RSU Cipto \\ Mangunkusumo Jakarta
}

\begin{abstract}
This researach was aimed to describe the risk factor profile of pediatric patients with allergic rhinitis. 1792 medical records of outpatients pediatric allergy immunology clinic in Cipto Mangunkusumo Hospital from 1997 to 2005. Fifty patients were diagnosed with allergic rhinitis and $22 \%$ of them were having allergic rhinitis with bronchial asthma .Allergic rhinitis were identified higher in boys (62\%) than girls (38\%) and ranged from 5 months to 13 years and 8 months old. Atopic history were identified in 24 patients (48) while atopic history in patient family were identified in mother (42\%), father (40\%), and siblings (24\%). Total IgE serum increased in 35 patients (88,57\%) while total eosinophil serum increased in 28 patients (80\%). The most common aeroallergen by skin prick test was house dust mite (36\%) and the most common food allergen was shrimp (40\%). There were several factors that contribute to the development of allergic rhinitis such as age, sex, family atopic history and increasing in total IgE serum and total eosinophil serum. House dust mite and shrimp were the most common allergen identified in allergic rhinitis.
\end{abstract}

Keywords: allergic rhinitis, risk factors, pediatric

\section{PENDAHULUAN}

Rinitis adalah peradangan lapisan mukosa hidung. Gejala rinitis alergi berupa bersin (5-10 kali berturut-turut), rasa gatal (pada mata, telinga, hidung, tenggorok, dan palatum), hidung berair, mata berair, hidung tersumbat, post nasal drip, tekanan pada sinus, dan rasa lelah. Rinitis alergi menjadi masalah kesehatan global yang menyerang 5-50\% penduduk. Anak dan dewasa muda dengan rinitis alergi mengalami gangguan aktifitas fisik, maupun sosial dan terjadi perasaan mental tidak sehat (1).

Rinitis alergi musiman adalah rinitis yang dipicu oleh allergen serbuk sari, spora lumut selama musim semi, musim panas, maupun musim gugur. Rinitis alergi perenial menunjukkan gejala hayfever sepanjang tahun yang dipicu oleh alergen dalam rumah, seperti: debu rumah tangga, kecoa, spora lumut, bulu binatang, dan sebagainya. ARIA (Allergic Rhinitis and its Impact on Asthma) membuat klasifikasi rinitis alergi berdasarkan lama dan seringnya timbul gejala, dan berdasarkan gejala yang dialami pasien, bukan berdasarkan penyebab. Klasifikasi baru membagi rinitis alergi menjadi 2 kategori, yaitu intermiten dan persisten. Kategori intermiten adalah apabila gejala timbul kurang dari 4 hari per minggu atau kurang dari 4 minggu,

Jurnal Kedokteran Brawijaya, Vol. XXIII, No.3,Desember 2007 Korespondensi: Ganung Harsono; Bagian Anak, RSUD Dr. Moewardi Surakarta; JI. Kol Soetanto 132, Surakarta 57126; email: ganungharsono@yahoo.com sedangkan kategori persisten adalah apabila gejala timbul lebih dari 4 hari dalam seminggu dan berlangsung lebih dari 4 minggu (2).

Penderita rinitis alergi mempunyai resiko berlanjut menjadi asma (3). Rinitis alergi dan asma merupakan penyakit inflamasi yang sering timbul bersamaan. Dokter perlu mengevaluasi adanya riwayat asma pada pasien dengan rinitis alergi yang menetap. Evaluasi dapat dilakukan melalui pemeriksaan sinar $X$, pemeriksaan adanya sumbatan saluran nafas sebelum dan sesudah pemberian bronkodilator.

Bukti epidemiologis adanya hubungan antara rinitis dan asma adalah 1) prevalensi asma meningkat pada rinitis alergi dan non alergi; 2) rinitis hampir selalu dijumpai pada asma; 3) rinitis merupakan faktor resiko terjadinya asma; dan, 4) pada persisten rinitis terjadi peningkatan hipereaktivitas bronkus non spesifik. Penelitian epidemiologi menunjukkan prevalensi rinitis alergi dan asma meningkat di seluruh dunia termasuk di AS (4). Sekitar 56 juta orang atau $20 \%$ penduduk AS menderita rinitis alergi dan $5 \%$ menderita asma (5). Berbagai penelitian menunjukkan 7894\% penderita asma pada remaja dan dewasa juga menderita rinitis alergi, dan $38 \%$ penderita rinitis alergi juga menderita asma.

Adanya potensi keterkaitan antara rinitis alergi dan asma menunjukkan pentingnya pengendalian rinitis alergi. Disamping itu rinitis alergi yang tidak dikendalikan dengan baik akan mengganggu aktifitas sehari-hari. Strategi 
pengendalian rinitis harus diawali dengan mengenali berbagai faktor yang menjadi resiko atau pencetus terjadinya rinitis alergi. Penelitian ini dilakukan untuk mengkaji faktor-faktor yang diduga menjadi resiko terjadinya rinitis alergi pada pasien anak .

\section{METODE}

Penelitian dilakukan dengan pendekatan deskriptif cross sectional berdasarkan catatan medik seluruh pasien yang berobat di poliklinik alergi imunologi anak rumah sakit Dr. Cipto Mangunkusumo (RSCM) Jakarta tahun 1997 sampai 2005. Didapatkan 1792 catatan medik pasien yang berobat dengan 50 pasien yang didiagnosis rinitis alergi. Diagnosis rinitis alergi ditegakkan berdasarkan standar pelayanan medis yang dipakai di Departemen IImu Kesehatan Anak, RSCM. Faktor resiko yang dikaji dalam penelitian ini meliputi jenis kelamin, riwayat atopi pada pasien dan keluarga, kadar IgE serum total, jumlah eosinofil serum total dan alergen makanan serta hirup.

\section{HASIL PENELITIAN}

Didapatkan 50 pasien rinitis alergi berumur 5 bulan sampai berumur 13 tahun 8 bulan dengan proporsi laki-laki lebih banyak dibandingkan perempuan (tabel 1). Tiga puluh sembilan pasien $(78 \%)$ didiagnosis dengan rinitis alergi saja dan 11 pasien (22\%) dengan diagnosis rinitis alergi disertai asma bronkiale. Hasil juga menunjukkan bahwa prosestase penderita laki-laki maupun perempuan pada semua golongan umur hampir sama, kecuali pada umur 6-12 tahun, penderita rinitis alergi laki-laki lebih banyak dari pada perempuan.

Tabel 1. Umur dan Jenis Kelamin Pasien Rinitis Alergi

\begin{tabular}{ccc}
\hline \multirow{2}{*}{ Umur (tahun) } & \multicolumn{2}{c}{ Jenis kelamin } \\
\cline { 2 - 3 } & Laki-laki & Perempuan \\
\hline 5 bl-2 th & $9(18 \%)$ & $7(14 \%)$ \\
$3-5$ th & $5(10 \%)$ & $5(10 \%)$ \\
$6-12$ th & $15(30 \%)$ & $7(14 \%)$ \\
$>13$ th & $2(4 \%)$ & $0(0 \%)$ \\
\hline Total & $31(62 \%)$ & $19(38 \%)$ \\
\hline
\end{tabular}

Riwayat atopi dicatat pada 50 pasien rinitis alergi. Riwayat atopi didapatkan pada 24 pasien (48 \%) dari pasien rinitis alergi (Tabel 2). Prosentase atopi pada penderita lakilaki maupun perempuan pada semua golomgam umur hampir sama, kecuali pada umur 6-12 tahun, penderita atopi laki-laki lebih banyak dari pada perempuan.
Tabel 2. Riwayat Atopi Positif pada Pasien Rinitis Alergi

\begin{tabular}{ccc}
\hline \multirow{2}{*}{ Umur } & \multicolumn{2}{c}{ Riwayat Atopi Positif } \\
\cline { 2 - 3 } & Laki-laki & Perempuan \\
\hline 5 bl-2 th & $4(8 \%)$ & $4(8 \%)$ \\
$3-5$ th & $3(6 \%)$ & $2(4 \%)$ \\
$6-12$ th & $9(18 \%)$ & $1(2 \%)$ \\
$>13$ th & $1(2 \%)$ & $0(0 \%)$ \\
\hline Jumlah & $17(34 \%)$ & $7(14 \%)$ \\
\hline
\end{tabular}

Riwayat atopi pada keluarga ditemukan pada 50 pasien rinitis alergi. Riwayat atopi terbanyak ditemukan pada ibu $(42 \%)$ dan selanjutnya berturut-turut pada ayah $(40 \%)$, kakek (28\%), saudara kandung $(24 \%)$ dan nenek sebesar $14 \%$ (tabel 3)

Tabel 3. Riwayat Atopi pada Keluarga Pasien Rinitis Alergi $(n=50)$

\begin{tabular}{ccc}
\hline Hubungan Keluarga & \multicolumn{2}{c}{ Riwayat Atopi Keluarga Positip } \\
\cline { 2 - 3 } & Jumlah & Persentase \\
\hline Ibu & 21 & $42 \%$ \\
Ayah & 20 & $40 \%$ \\
Kakek & 14 & $28 \%$ \\
Nenek & 7 & $14 \%$ \\
Kakak & 7 & $14 \%$ \\
Adik & 5 & $10 \%$ \\
\hline
\end{tabular}

Dari pemeriksaan $\lg E$ serum total terhadap 35 pasien rinitis alergi, 31 pasien $(88,57 \%)$ mengalami peningkatan IgE serum total. Peningkatan tersebut paling banyak dijumpai pada pasien berusia 1-5 tahun yaitu sebanyak 17 pasien atau $48,57 \%$ (tabel 4 ).

Tabel 4. Kadar IgE Serum Total pada Pasien Rinitis Alergi $(n=35)$

\begin{tabular}{|c|c|c|}
\hline \multirow{2}{*}{ Umur } & \multicolumn{2}{|c|}{ Kadar IgE Serum Total } \\
\cline { 2 - 3 } & Normal & Meningkat \\
\hline$<1$ tahun $(\mathrm{N}:<15)$ & $0(0,00 \%)$ & $1(2,86 \%)$ \\
$1-5$ tahun $(\mathrm{N}:<60)$ & $1(2,86 \%)$ & $17(48,57 \%)$ \\
$6-9$ tahun $(\mathrm{N}:<90)$ & $1(2,86 \%)$ & $11(31,43 \%)$ \\
$10-15$ tahun $(\mathrm{N}:<200)$ & $2(5,71 \%)$ & $2(5,71 \%)$ \\
\hline Jumlah & $4(11,43 \%)$ & $31(88,57 \%)$ \\
\hline
\end{tabular}

Pemeriksaan jumlah eosinofil serum total dilakukan pada 35 pasien rinitis alergi. Didapatkan peningkatan jumlah eosinofil serum total pada 28 pasien $(80 \%)$ yang terdiri dari 15 pasien laki-laki $(42,86 \%)$ dan 13 pasien perempuan atau $37,14 \%$ (tabel 5 ) 
Tabel 5. Jumlah Eosinofil Darah Total pada Pasien Rinitis Alergi menurut Jenis Kelamin $(n=35)$

\begin{tabular}{cccc}
\hline Eosinofil & \multicolumn{2}{c}{ Jenis Kelamin } & \multirow{2}{*}{ Jumlah } \\
\cline { 2 - 3 } Darah Total & Laki-laki & Perempuan & \\
\hline$<300 / \mathrm{mm}^{3}$ & $6(17,14 \%)$ & $1(2,86 \%)$ & $7(20 \%)$ \\
$>300 / \mathrm{mm}^{3}$ & $15(42,86 \%)$ & $13(37,14 \%)$ & $28(80 \%)$ \\
\hline
\end{tabular}

Pada pemeriksaan eosinofil darah total dari 35 pasien rinitis alergi, peningkatan paling banyak dijumpai pada anak usia 5 bulan sampai 2 tahun, yaitu sebanyak 12 pasien $(34,28 \%)$ (tabel 6).

Uji kulit tusuk dengan alergen makanan dilakukan pada 25 pasien rinitis alergi. Hasil uji kulit tusuk alergen makanan yang positif berturut-turut sebagai berikut (tabel $7)$, udang $(40 \%)$, coklat $(32 \%)$, kuning telur $(24 \%)$, kacangkacangan $(20 \%)$, susu sapi $(16 \%)$, kedelai $(16 \%)$, ikan $(16 \%)$, putih telur (12\%) dan kepiting $(8 \%)$.

Uji kulit tusuk dengan alergen hirup dilakukan pada 25 pasien rinitis alergi. Hasil uji kulit tusuk alergen hirup yang positif berturut-turut sebagai berikut (tabel 8): tungau debu rumah (36\%), serpihan kulit anjing (36\%), serpihan kulit kucing $(32 \%)$, debu rumah (24\%), katun (24\%), kecoa $(20 \%)$, kapuk (20\%), bulu campuran $(16 \%)$, Aspergillus fumigatus (12\%), alternaria ( $8 \%$ ), bulu kelinci $4 \%)$, bulu burung (4\%), dan Candida albicans (4\%).

Tabel 6. Jumlah Eosinofil Darah Total pada Pasien Rinitis Alergi menurut Umur ( $n=35)$

\begin{tabular}{|c|c|c|c|c|c|}
\hline \multirow{2}{*}{ Eosinofil Total } & \multicolumn{4}{|c|}{ Umur } & \multirow{2}{*}{ Jumlah } \\
\hline & $5 \mathrm{bl}-2$ th & $3-5$ th & $6-12$ th & $>13$ th & \\
\hline$<300 / \mathrm{mm}^{3}$ & $1(2,86 \%)$ & $2(5,71 \%)$ & $3(8,57 \%)$ & $1(2,86 \%)$ & $7(20 \%)$ \\
\hline$>300 / \mathrm{mm}^{3}$ & $12(34,28 \%)$ & $5(14,28 \%)$ & $10(28,57 \%)$ & $1(2,86 \%)$ & $28(80 \%)$ \\
\hline
\end{tabular}

Tabel 7. Uji Kulit Tusuk Alergen Makanan yang Positif pada Pasien Rinitis Alergi $(n=25)$

\begin{tabular}{lcccc}
\hline \multicolumn{1}{c}{ Alergen Makanan } & \multicolumn{3}{c}{ Usia Uji Kulit Tusuk Positif } & \\
\cline { 2 - 4 } & 5 bulan-2 tahun & $\mathbf{3 - 5}$ tahun & $\mathbf{> 6}$ tahun & Jumlah \\
\hline Udang & 0 & 1 & 9 & $10(40 \%)$ \\
Coklat & 0 & 0 & 8 & $8(32 \%)$ \\
Kuning telur & 0 & 0 & 6 & $6(24 \%)$ \\
Kacang-kacangan & 1 & 1 & 3 & $5(20 \%)$ \\
Susu sapi & 2 & 0 & 2 & $4(16 \%)$ \\
Kedelai & 1 & 0 & 3 & $4(16 \%)$ \\
Ikan & 1 & 0 & 3 & $4(16 \%)$ \\
Putih telur & 0 & 0 & 3 & $3(12 \%)$ \\
Kepiting & 0 & 1 & 1 & $2(8 \%)$ \\
\hline
\end{tabular}

Tabel 8. Uji Kulit Tusuk Alergen Hirup yang Positif pada Pasien Rinitis Alergi $(n=25)$

\begin{tabular}{lcccc}
\hline \multirow{2}{*}{ Alergen Hirup } & \multicolumn{3}{c}{ Usia Uji Kulit Tusuk Positip } & \multirow{2}{*}{ Jumlah } \\
\cline { 2 - 4 } & 5 bulan-2 tahun & $\mathbf{3 - 5}$ tahun & $\mathbf{7 6 \text { tahun }}$ & \\
\hline Tungau debu rumah & 0 & 1 & 8 & $9(36 \%)$ \\
Serpihan kulit anjing & 0 & 3 & 6 & $9(36 \%)$ \\
Serpihan kulit kucing & 0 & 1 & 7 & $8(32 \%)$ \\
Debu rumah & 0 & 0 & 6 & $6(24 \%)$ \\
Katun & 1 & 1 & 4 & $6(24 \%)$ \\
Kecoa & 0 & 0 & 5 & $5(20 \%)$ \\
Kapuk & 0 & 1 & 4 & $5(20 \%)$ \\
Bulu (campuran) & 0 & 0 & 4 & $4(16 \%)$ \\
Aspergillus fumigatus & 0 & 1 & 2 & $3(12 \%)$ \\
Alternaria & 0 & 1 & 1 & $2(8 \%)$ \\
Bulu kelinci & 0 & 0 & 1 & $1(4 \%)$ \\
Bulu burung & 0 & 0 & 1 & $1(4 \%)$ \\
Candida albicans & 0 & 0 & 1 & $1(4 \%)$ \\
\hline
\end{tabular}




\section{DISKUSI}

Dari seluruh pasien yang berobat selama 1997-2005 (1792 pasien) sebanyak 50 pasien menderita rinitis alergi. Rinitis alergi ditemukan pada pasien berusia 5 bulan sampai 13 tahun 8 bulan. Rinitis alergi sering terjadi pada masa anak-anak, remaja, dan dewasa muda, dengan puncaknya pada usia 8-11 tahun, tetapi rinitis alergi bisa menyerang semua umur. Sebanyak $80 \%$ kasus terjadi pada usia sebelum 20 tahun.

Pada anak, rinitis alergi lebih banyak dijumpai pada laki-laki dibanding perempuan, tetapi pada orang dewasa prevalensi laki-laki dan perempuan hampir sama. Hasil penelitian pada pasien anak menunjukkan dari 50 pasien rinitis alergi, proporsi laki-laki $(62 \%)$ lebih banyak dibandingkan perempuan (38\%).

. Sebanyak 22\% pasien dengan rinitis alergi juga menderita asma bronkiale. Hal ini sejalan dengan fakta epidemiologis yang menunjukkan ada hubungan yang erat antara rinitis alergi dengan asma bronkiale. Berbagai penelitian menunjukkan $78-94 \%$ penderita asma pada remaja dan dewasa juga menderita rinitis alergi, dan $38 \%$ penderita rinitis alergi juga menderita asma. Disamping itu penderita rinitis alergi mempunyai kepekaan pada bronkus yang lebih tinggi dibanding anak yang sehat. Anak yang menderita asma-sedang lebih sering menderita rinitis alergi dibandingkan penderita asma-ringan. Oleh karena itu, rinitis alergi yang terkontrol dapat mencegah timbulnya serangan asma.

Faktor risiko terjadinya rinitis alergi meliputi (1) riwayat atopi keluarga; (2) lgE serum lebih tinggi daripada $100 \mathrm{IU} / \mathrm{mL}$ pada anak di bawah usia 6 tahun; (3) keluarga dengan sosial ekonomi yang tinggi; (4) paparan terhadap alergen rumah tangga seperti hewan dan tungau debu rumah tangga; (5) uji kulit tusuk positif. Faktor predisposisi terjadinya alergi adalah faktor genetik dan faktor lain misalnya pemaparan dengan virus-virus tertentu. Pemaparan alergen virus jangka lama dapat menyebabkan eksem, dermatitis atopi, hay fever dan asma. Hal ini dapat muncul bersamaan atau salah satu muncul lebih dulu.

Pada penelitian didapatkan $48 \%$ pasien mempunyai riwayat atopi. Riwayat atopi keluarga ditemukan pada ibu $(42 \%)$; ayah $(40 \%)$, dan pada saudara kandung $(24 \%)$. Atopi merupakan predisposisi genetik untuk membentuk antibodi alergi ( $\operatorname{lgE}$ ) dalam memberikan respons terhadap alergen spesifik. Atopi merupakan faktor risiko terjadinya asma dan rinitis alergi. Periode kritis sensitisasi alergen terjadi sampai usia dua atau tiga tahun (8). Apabila didapatkan riwayat atopi pada kedua orang tuanya, kemungkinan risiko rinitis alergi lebih besar dibandingkan apabila salah satu dari orang tuanya yang atopi, namun perlu diketahui bahwa rinitis alergi disebabkan multifaktorial. Seseorang tanpa riwayat keluarga atopi dapat menderita rinitis alergi. Individu atopi mewariskan kecenderungan terjadinya respons imun limfosit Th2 dengan pembentukan IgE-sel mast.

Reaksi alergi merupakan reaksi yang kompleks. Pertama-tama terjadi interaksi antara alergen dengan lg $\mathrm{E}$, dilanjutkan dengan mulai berfungsinya seluruh mediator inflamasi. Mediator yang dilepaskan adalah histamin, leukotrin, sitokin dan kemokin, kemudian terjadi akumulasi sel-sel inflamasi pada jaringan tempat reaksi alergi. Proses berikutnya adalah adesi selektif pada sel-sel epitel dilanjutkan dengan diapedesis ke jaringan di bawahnya karena pengaruh kemotaksis. Reaksi alergi ditandai dengan peningkatan $\lg E$ yang menyebabkan reaksi sistim imun sehingga terjadi peradangan.

Paparan terhadap alergen tungau debu rumah, kecoa, kucing, anjing dan hewan piaraan lain, serbuk sari atau alergen lain untuk jangka lama dengan konsentrasi rendah menyebabkan presentasi alergen oleh antigen presenting cell (APC) terhadap CD41 limfosit, yang akan melepaskan IL3, IL4, IL5, GM-CSF dan sitokin lainnya. Hal ini meningkatkan produksi lgE terhadap alergen tersebut oleh sel plasma, proliferasi sel mast dan infiltrasi mukosa saluran napas, dan eosinofilia (10).

$\lg \mathrm{E}$ serum total merupakan pemeriksaan kadar $\lg \mathrm{E}$ total dalam darah tanpa memandang spesifikasi. Walaupun pada penderita rinitis alergi terjadi peningkatan kadar lgE serum total, uji ini tidak sensitif dan tidak spesifik untuk rinitis alergi. Sebanyak 50\% penderita rinitis alergi mempunyai kadar lgE serum total yang normal sedangkan $20 \%$ anak yang tidak menderita rinitis alergi dapat terjadi peningkatan kadar IgE serum total. Untuk menegakkan diagnosis, uji ini biasanya tidak digunakan sendirian. Pada beberapa kasus, uji kadar lgE serum total berguna apabila dikombinasikan dengan pemeriksaan lainnya. Sebaliknya, penting untuk mengukur kadar lgE serum spesifik. Pada penelitian ini didapatkan peningkatan IgE serum total pada $88,57 \%$ pasien, sedangkan hasil normal didapatkan pada $11,43 \%$ pasien. Kadar IgE yang meningkat paling banyak dijumpai pada anak usia 1-5 tahun yaitu sebesar $48,57 \%$ dari seluruh anak yang diperiksa.

Eosinofil merupakan sel yang sering dijumpai pada penderita rinitis, sinusitis, dan asma bronkiale. Peningkatan jumlah eosinofil darah menunjang diagnosis rinitis alergi namun harus dikombinasikan dengan pemeriksaan lainnya untuk penegakan diagnosis. Hasil penelitian menunjukkan dari 35 penderita rinitis alergi; terdapat peningkatan jumlah eosinofil darah pada $80 \%$ pasien dan jumlah eosinofil darah normal pada $20 \%$ pasien. Peningkatan jumlah eosinofil darah lebih banyak dijumpai pada laki-laki (42,86\%) dibandingkan dengan perempuan (37,14\%). Peningkatan eosinofil paling banyak dijumpai pada anak usia 5 bulan-2 tahun $(34,28 \%)$.

Uji kulit digunakan secara luas untuk menunjukkan reaksi alergi yang diperantarai lgE. Diagnosis alergi psesifik 
dapat dipastikan bila uji kulit dilaksanakan dengan tepat. Karena hasil dan interpretasinya cukup rumit maka dianjurkan uji kulit ini dilakukan oleh tenaga medis yang profesional. Uji kulit dilakukan untuk memastikan adanya sensitisasi terhadap suatu alergen tetapi tidak menunjukkan bahwa seseorang sedang terpapar alergen. Anamnesis paparan alergen berguna untuk mengidentifikasi pencetus reaksi alergi spesifik. Pencetus yang sering dijumpai pada pasien asma alergi meliputi binatang, tungau debu rumah, kecoa, spora lumut dan serbuk sari bunga. Pencetus non alergi meliputi infeksi viral saluran napas atas, latihan fisik, cuaca yang sangat panas atau dingin dan berbagai macam iritan.

Alergen makanan yang paling sering dijumpai pada penelitian ini adalah udang (40\%) dan selanjutnya berturutturut coklat $(32 \%)$, kuning telur $(24 \%)$, kacang-kacangan $(20 \%)$, susu sapi $(16 \%)$, kedelai $(16 \%)$, ikan $(16 \%)$, putih telur $(12 \%)$ dan kepiting (8\%). Alergen hirup paling banyak dijumpai adalah tungau debu rumah $(36 \%)$ dan serpihan kulit anjing (36\%), selanjutnya berturut-turut serpihan kulit kucing (32\%), debu rumah (24\%), katun (24\%), kecoa (20\%), kapuk (20\%), bulu (campuran) $(16 \%)$, aspergilus fumigatus $(12 \%)$, alternaria $(8 \%)$, bulu kelinci $(4 \%)$, bulu burung (4\%), dan Candida albicans (4\%).

\section{KESIMPULAN}

Beberapa faktor yang diduga meningkatkan resiko rhinitis alergi ditemukan pada penelitian ini meliputi jenis kelamin, riwayat atopi keluarga, peningkatkan kadar lgE serum total, peningkatan jumlah eosinofil dan uji kulit tusuk positif pada alergen makanan dan hirup. Anak laki-laki ditemukan lebih banyak menderita rinitis alergi $(62 \%)$ dibandingkan anak perempuan (38\%). Riwayat atopi pada keluarga ditemukan dengan urutan proporsi terbesar pada ibu dan selanjutnya ayah, kakek, saudara kandung dan nenek.

Peningkatan lgE serum total ditemukan pada $88,57 \%$ pasien. Anak berusia 1-5 tahun paling banyak mengalami peningkatan $\lg E$ serum total yaitu sebesar $48,57 \%$ dari seluruh pasien. Peningkatan jumlah eosinofil darah juga ditemukan pada $80 \%$ pasien.

Uji kulit tusuk terhadap alergen makanan dari 25 pasien didapatkan hasil positif terbanyak pada udang. Sedangkan alergen hirup yang teridentifikasi positif pada uji kulit tusuk ditemukan terbanyak pada tungau debu rumah.

Sejalan dengan fakta epidemiolgis lain penelitian menemukan $22 \%$ pasien rinitis alergi juga menderita asma bronkiale. Oleh karena itu pengendalian rinitis alergi juga dapat menurunkan risiko penyakit asma. Disamping itu perlu kajian lebih lanjut tentang berbagai faktor yang meningkatkan resiko terjadinya rinitis alergi.

\section{DAFTAR KEPUSTAKAAN}

1 Girish VV, Cleveland MM, Raghubir KM et al. Allergic rhinitis and asthma severity. Journal of the World Allergy Organization; Jan/Feb.2004; 16 (1): 15-9.

2 Christine DV, Agnes L. Devinition and management of persistent allergic rhinitis -the ARIA guidelines. J of the World Allergy Organization; March/April 2005; 17 (2): 78-9

3 Bernstein JA. Cost-benefit analysis for allergen immunotherapy. Immunol Allergy Clinics of N America 2000; 20: 593607.

4 Kay AB. Allergy and allergic diseases. N Engl J Med 2001; 344: 30-7.

5 Naclerio RM. Allergic rhinitis. N Engl J Med 1991; 325: 860-9.

6 Von Mutius E, Martinez FD, Fritzsch C, et.al. Prevalence of asthma and atopy in two areas of East and West Germany. Am J Respir Crit Care Med 1994; 149: 358-64.

7 Bernstein JA. Allergic rhinitis. Postgraduate Medicine; 124-32.

8 Humbert M, Durham SR, Ying S, et.al. IL-4 and IL-5 mRNA and protein in bronchial biopsies from patients with atopic and nonatopic asthma:evidence against "intrinsic" asthma being a distinct immunopathologic entity. Am J Respir Crit Care Med 1996; 154: 1497-504

9 Busse WW, Lemanske RF. Asthma. N Engl J Med 2001; 344: 350-62.

10 Evans III R. Epidemiology and natural history of asthma, allergic rhinitis, and atopic dermatitis. In: Middleton EJ, Reed CE, Ellis EF, et al, eds. Allergy: principles and practice. 4th edition. St. Louis: Mosby 1993; $1109-36$. 